\title{
Arsitektur Atap Masjid Di Kalimantan Selatan
}

\section{Bambang Sakti Wiku Atmojo}

Keywords: mosque, ancient, borneo, architecture, typology

\section{How to Cite:}

Atmojo, B. S. W. (2001). Arsitektur Atap Masjid Di Kalimantan Selatan. Berkala Arkeologi, 21(2), 68-76. https:// doi.org/10.30883/jba.v21i2.842

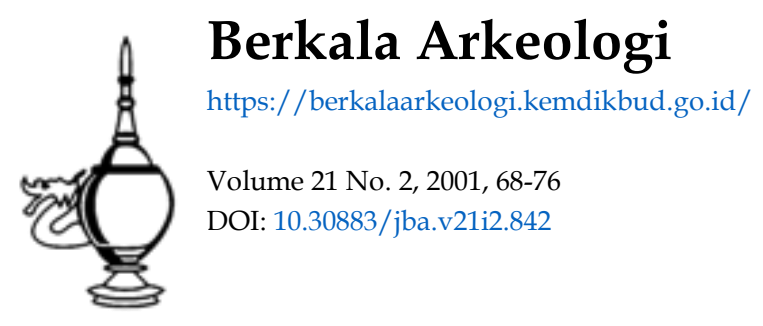

\section{(c) (1)(2)}

This work is licensed under a Creative Commons Attribution-NonCommercial-ShareAlike 4.0 International License. 


\section{ARSITEKTUR ATAP \\ MASJID DI KALIMANTAN \\ SELATAN \\ Bambang Sakti Wiku Atmojo \\ (Balai Arkeologi Banjarmasin)}

\section{A. Pendahuluan}

Masjid merupakan salah satu hasil kebudayaan Islam yang bersifat fisik, yang berkaitan dengan unsur kebutuhan keduniawian maupun kerohanian. Dalam hal ini masjid berfungsi sebagai tempat melaksanakan kegiatan keagamaan, sosial, maupun politik. Dasar pendirian masjid adalah adanya perintah untuk melaksanakan ibadah salat bagi umat Islam. Meskipun pada hakekatnya semua tempat di permukaan bumi adalah masjid, tetapi supaya terjaga maka didirikanlah masjid sebagai suatu bangunan khusus (Atjeh, $1955: 3$ ).

Sumber kebudayaan Islam adalah Al Quran dan Hadits. Akan tetapi, dari keduanya tidak ada ketentuan tentang aspek fisik suatu bangunan maka terbuka kelonggaran untuk berkreasi mengenai arsitektur masjid. Oleh karena itu maka muncullah beraneka ragam kreasi arsitektur masjid sesuai dengan kondisi zaman, budaya masyarakat, dan lingkungan di sekitarnya (Wiryoprawiro, 1986 : 7). Meskipun demikian bangunan masjid di berbagai tempat senantiasa akan lebih menonjolkan arsitektur lokal yang lebih dominan. Tidak menutup kemungkinan adanya saling pengaruh antar arsitektur masjid di satu tempat dengan tempat lain.

Di Kalimantan Selatan arsitektur lokal sangat menonjol, yang antara lain ditunjukkan dengan bentuk atap, ornamen, dan dinding. Sebagaimana dengan daerah-daerah lain di Indonesia, bentuk atap yang dominan adalah tumpang yang bahannya terbuat dari dari sirap. Ornamen atau ragam hias yang berupa bentuk-bentuk flora menunjukkan tipe lokal yang sangat kental, misalnya bentuk-bentuk burung enggang, bunga tanjung, dan lain-lain. Karena berada di daerah tropis yang banyak hutannya maka penggunaan bahan kayu sangat dominan.

Dari sejumlah masjid kuna di Kalimantan Selatan hampir semua atapnya berbentuk tumpang, baik tumpang 2 maupun 3 . Di antara atap tumpang satu dengan yang lainnya ditutup dengan dinding kayu terdapat sejumlah jendela kaca. Kadang - kadang jendela kaca tersebut merupakan bagian yang dominan di bagian tersebut. Bagian puncak atap hampir semuanya berbentuk kubah, baik dibuat dari seng maupun kayu. Puncak yang berbentuk segitiga yang merupakan arsitektur asli setempat sangat jarang didapatkan. 


\section{B. Atap Masjid Kuna di Kalimantan Selatan}

\section{Masjid Su'ada, Wasah Hilir, Hulu Sungai Selatan}

Atap ruangan induk Masjid Su'ada bersusun tiga (atap tumpang tiga) yang cukup tinggi, makin ke atas makin mengecil. Bentuk atap persegi empat, yang paling atas meruncing ditutup dengan hiasan puncak. Pada tiap sudut atap, yaitu pada ujung bubungan dihias dengan cabang berukir atau simbar yang mencuat ke atas. Cabang berukir ini berupa papan berukir sulur-suluran yang merupakan hiasan khas bangunan tradisional Kalimantan Selatan. Atap bagian bawah didukung sejumlah tiang yang berjajar keliling sisi luar masjid. Antara atap tumpang pertama dengan tumpang kedua dan seterusnya ditutp dengan dinding kayu yang diselingi dengan jendela kaca sehingga intensitas cahaya yang masuk cukup memadai.

Hiasan puncak bangunan induk dibuat dari bahan logam berwarna putih, berupa kuncup bunga bersusun dengan bulatan pada ujungnya yang menyerupai kepala putik, cabang, daun dan kuncup. Secara keseluruhan hiasan tersebut mengesankan sebuah tangkai bunga yang tampak indah.

Pada bagian pengimaman atapnya bersusun dua berbentuk segi delapan, dan memiliki kubah berbentuk oval yang dibuat dari kayu. Pada bagian atas juga terdapat mahkota pataka seperti pada bangunan induk.

\section{Masjid Taqwa di Kandangan, Hulu Sungai Selatan}

Atap ruangan induk masjid Taqwa tumpang dua berbentuk segi empat, atap kedua lebih kecil daripada atap pertama. Antara atap pertama dengan kedua terdapat jendela yang terbuat dari kaca. Kedua bagian atap tersebut terbuat dari sirap, tidak ada hiasan apapun pada sudut-sudutnya. Di atas atap tumpang kedua terdapat kemuncak berbentuk kubah. Di atas kubah tersebut terdapat hiasan puncak berwarna putih, berupa bulatan-bulatan yang diakhiri dengan lambang bulan sabit, bintang, serta baling-baling.

Seperti halnya pada bagian ruangan induk, atap bagian mihrab juga tumpang dua, terbuat dari kayu sirap. Atap bagian bawah berbeda dengan atap ruangan induk, yaitu mempunyai bubungan, sehingga tidak datar tetapi agak lancip. Di bagian atas berupa kemuncak berbentuk kubah yang ditambahi dengan hiasan berupa bulatan-bulatan yang diakhiri dengan lambang bulan sabit, bintang dan baling-baling, yang semuanya terbuat dari logam. 


\section{Masjid Jamik Banjarmasin}

Masjid Jamik Banjarmasin terletak di tengah-tengah kota yang merupakan daerah perkampungan lama. Secara keseluruhan atap ruangan induk masjid berbentuk tumpang empat, terbuat dari sirap. Antara atap tumpang pertama dengan kedua ditutup dengan dinding kayu sehingga tidak ada lubang jendela. Antara atap tumpang kedua dengan ketiga dan antara atap ketiga dengan keempat selain ditutup kayu juga terdapat jendela dari kaca yang dihiasi dengan fresco. Bagian puncak berbentuk kubah terbuat dari seng yang dikelilingi dengan pagar kecil. Dengan demikian apabila dihitung secara keseluruhan atap masjid jamik tersebut tumpang lima.

Di bagian depan terdapat pintu gerbang yang atapnya bertingkat dua. Atap bagian bawah seperti halnya pada ruangan induk berupa sirap yang melandai, sedangkan atap bagian atas terbuat dari beton berbentuk datar. Pada sudut-sudut atap bagian atas tersebut terdapat hiasan berbentuk tiang dan pada bagian depan terdapat hiasan garisgaris vertikal dan horizontal menyerupai matahari yang bersinar. Di atas atap kedua tersebut terpat kemuncak berbentuk kubah yang disangga oleh menara rendah berbentuk segi delapan. Pada bagian tersebut juga terdapat jendela yang dibuat dari kaca, yang secara keseluruhan berjumlah delapan, sesuai dengan jumlah segi delapan.

\section{Masjid Pantai Hambawang, Hulu Sungai Tengah}

Atap ruangan induk masjid Pantai Hambawang berupa atap tumpang berjumlah dua yang dibuat dari sirap. Antara atap tumpang pertama dengan kedua terdapat sela-sela yang cukup tinggi, dibuat dari kayu dan kaca. Di atas atap kedua terdapt kemuncak berbentuk kubah setengah bulatan yang disangga menara pendek segia enam, di atasnya terdapat hiasan berupa bulatan dan lambang bulan sabit. Dengan demikian secara keseluruhan atap ruangan induk berjumlah tumpang tiga.

Di bagian depan terdapat ruangan semacam teras terbuka berbentuk segi empat. Sebagaimana ruangan induk, atap pada ruangan teras ini juga tumpang dua yang di atasnya terdapat kubah setengah lingkaran disangga oleh menara pendek berbentuk segi empat. Atap bagian bawah dikelilingi dengan pagar, yang pada setiap sudutnya terdapat menara kecil-kecil. Di bagian atas kubah terdapat hiasan berbentuk tongkat meruncing berwarna putih.

Bagian samping kanan masjid ini berbeda sama sekali dengan masjid-masjid yang lain, yaitu berupa atap datar yang di atasnya terdapat kubah bertingkat dua. Kedua kubah tersebut berbentuk setengah lingkaran yang masing-masing disangga oleh menara pendek berbentuk segi enam. Jendela kaca pada kedua menara pendek tersebut berwarna jingga, biru, hijau, dan ungu. Dilihat dari bentuknya ada 
kemungkinan bahwa pada masa lalu tempat tersebut merupakan menara yang dipakai untuk mengumandangkan adzan.

\section{Masjid Tambarangan di Kabupaten Tapin}

Atap ruangan induk masjid Tambarangan berbentuk tumpang berjumlah dua. Tumpang pertama seperti atap tumpang pada umumnya yaitu terbuat dari sirap, berbentuk segi empat yang makin ke tengah makin naik. Atap kedua berupa atap datar, pada kempat sudutnya terdapat menara-menara kecil yang puncaknya berupa kubah bawang. Di atas atap datar tersebut masih terdapat kemuncak berupa kubah yang bagian ujung atas meruncing. Antara atap pertama dengan kedua dan antara atap kedua dengan kubah terdapat jendela kaca sebagai sarana ventilasi udara dan sirkulasi cahaya.

Di depan ruangan induk terdapat ruangan terbuka (tanpa dinding) yang memiliki atap tumpang satu. Di atas atap tersebut terdapat kemuncak berbentuk kubah yang disangga menara pendek berbentuk segi delapan, yang juga memiliki jendela kaca. Seperti halnya pada kubah atap ruangan induk, kubah di atas ruangan ini juga dibuat dari seng yang bagian ujung atasnya meruncing.

Di samping kanan dan kiri ruangan induk masing-masing terdapat sebuah menara yang bagian dasarnya memiliki ruangan berdinding kayu. Atap pada kedua menara tersebut berbenuk datar dengan bahan seng. Bagian tengah menara berbentuk bulat sedangkan bagian atas berbentuk segi enam berjendela kaca, dengan kemuncak berupa kubah dari seng yang bentuknya mirip topi.

\section{Masjid di Desa Hamalau, Kabupaten Tapin}

Masjid di Desa Hamalau berbentuk segi empat hanya memiliki ruangan induk tanpa ada teras yang mengelilingi. Atapnya berupa tumpang yang dibuat dari sirap. Atap pertama dan kedua berbentuk segi empat, sedangkan atap ketiga berbentuk segi delapan. Sebagaimana halnya atap tumpang secara umum, atap tumpang pertama pada masjid tersebut lebih besar daripada tumpang kedua dan seterusnya. Antara atap tumpang pertama dengan kedua berupa ruangan tertutup berbentuk segi empat berjendela kaca, sedangan antara apa tumpang kedua dengan ketiga berupa ruangan berbentuk segi enam.

Bagian paling atas berupa kubah dengan hiasan puncak berupa bulatan dan lambang bulan sabit. Berbeda dengan kubah masjid secara umum, kubah pada masjid tersebut dibuat dari sirap. Dengan demikian dapat dikatakan bahwa hampir semua bagian masjid tersebut dibuat dari bahan kayu kecuali hiasan kubahnya. 


\section{Majid Jamik di Desa Pandulangan, Alabio, Hulu Sungai Utara}

Masjid Jamik di Desa Pandulangan berbentuk segi empat dan terdapat teras yang mengelilinginya. Atap teras dan ruangan induk pada masjid tersebut menyatu, berbentuk atap tumpang berjumlah tiga. Atap tumpang pertama dan kedua berbentuk segi empat, sedangkan atap tumpang ketiga beberbentuk segi enam yang pada setiap sudutnya disangga tiang kecil. Ruangan antara atap tumpang pertama dengan kedua berbentuk segi empat, sedangkan ruangan antara atap tumpang kedua dengan ketiga berbentuk segi enam.

Bagian paling atas berbentuk segi enam berupa bentuk peralihan antara kubah dengan bentuk segitiga yang merupakan bentuk asli Kalimantan Selatan. Di atas "kubah" tersebut terdapat tambahan hiasan berupa semacam menara kecil dengan kemuncak berbentuk atap segi empat runcing dan ujungng berupa lambang bulan sabit.

\section{Arsitektur Atap}

Dalam agama Islam tidak ada aturan yang mengharuskan masjid berbentuk seragam. Hal tersebut sepenuhnya diserahkan kepada kreasi manusia untuk membangun masjid seperti yang dikehendaki. Dengan demikian muncul beraneka ragam bentuk masjid, yang tersebar di berbagai belahan permukaan bumi. Ketidakseragaman arsitektur ini terdapat baik pada bagian dinding, tiang, pola pengaturan ruang, maupun pada bagian atap.

Khusus mengenai bagian atap merupakan bagian yang paling menonjol perbedaannya bila dibandingkan dengan bagian-bagian yang lain. Biasanya bagian inilah yang sangat kentara memunculkan karakter arsitektur suatu wilayah tertentu. Di Indonesia secara umum bentuk arsitekturalnya adalah atap tumpang, yaitu bentuk atap bertingkat 2,3 , atau 4 yang makin ke atas makin mengecil dan diakhiri dengan kemuncak yang bentuknya tidak selalu sama untuk setiap daerah. Meskipun demikian ada satu bentuk kemuncak yang sangat populer yaitu mahkota atau daun-daun nanas .

Sebagaimana sudah diuraikan di depan, atap tumpang merupakan bentuk yang sangat populer di Kalimantan Selatan. Kalau di sejumlah daerah yang lain atap masjid dibuat dari seng, maka di Kalimantan Selatan ini atapnya dibuat dari kayu sirap. Di Kalimantan yang merupakan daerah berhutan tropis sangat kaya dengan kayu sehingga pembuatan bahan bangunan lebih banyak memakai kayu dibandingkan dengan bahan lain. Hal tersebut sesuai dengan salah satu aspek arsitektur yaitu mempergunakan sebanyak mungkin bahan lokal sebagai sarana adaptasi dengan lingkungan. 
Bentuk atap tumpang memungkinkan sirkulasi udara dan cahaya lebih bebas dibandingkan dengan bentuk-bentuk yang lain. Hal ini terjadi karena aliran udara dari atas, yaitu sela-sela antara atap tumpang, mengalir ke bawah sehingga berakibat suasana di dalam ruangan terasa lebih nyaman. Cahaya selain masuk dari pintu juga melalui jendela baik yang terdapat di bagian dinding maupun sela-sela antar atap. Situasi seperti itu seringkali mengakibatkan kondisi dalam ruangan masjid menjadi lebih terasa bernuansa sakral. Situasi tersebut berbeda dengan masjid-masjid baru yang lebih banyak menampilkan bentuk atap datar atau bukan atap tumpang.

Bentuk kemuncak ada tiga yaitu limas segi tiga yang berjumlah empat sisi, kubah dan peralihan antara segi tiga ke kubah yang berupa bentuk limas segi enam. Segitiga atau meruncing ke atas merupakan bentuk asli Kalimantan Selatan yang dinamakan Sungkul. Bentuk limas tersebut pada umumnya hanya terdapat pada bangunan masjid yang mempergunakan atap tumpang, biasanya merupakan atap tumpang paling atas (Darwis dan Rifai Abu, 1986: 145).

Atap yang berbentuk kubah merupakan arsitektur asing. Di Dunia Islam bentukbentuk kubah ada beberapa macam, yang dikenal dengan nama langgam. Langgam kubah ini dinamakan sesuai dengan asal wilayah muncul dan persebarannya, sehingga dikenal langgam Mesir, Siria, India, dan sebagainya. Berbagai bentuk kubah tersebut kemudian tersebar ke berbegai negara seiring dengan perkembangan agama Islam di berbagai belahan dunia, termasuk Indonesia. Dengan demikian sebenarnya dari bentuk kubah ini akan dapat diketahui asal persebaran agama Islam di berbagai wilayah tertentu.

Secara umum bentuk kubah pada masjid-masjid kuna di Kalimantan Selatan ada empat jenis. Jenis pertama berupa kubah berbentuk bawang, misalnya yang terdapat pada Masjid Taqwa di Kandangan, Masjid Jamik banjarmasin, dan Masjid di Bamban, Hulu Sungai Selatan. Jenis kedua berupa kubah yang berbentuk seperti topi, misalnya pada masjid di Pantai Hambawang dan masjid di Tambarangan. Bentuk ketiga berupa kubah segi enam misalnya pada masjid di Hamalau, dan Masjid Jamik Pandulangan, Alabio. Bentuk keempat adalah kubah berbentuk bulat penuh misalnya yang terdapat pada masjid di Sungai Banar dan Tambarangan.

Bentuk kubah bawang merupakan kubah yang berasal dan banyak tersebar di asia Selatan, sehingga populer sebagai kubah langgam India. Bentuk-bentuk yang lain yaitu bulat dan seperti topi merupakan langgam negara-negara Timur Tengah. Bentuk kubah segi enam merupakan bentuk asli Kalimantan Selatan, karena pada umumnya kubah yang berasal dari luar negeri langsung membulat tanpa memiliki sudut. Kubah segi enam tersebut memliki sudut sebanyak enam buah sehingga dapat dikatakan merupakan bentuk peralihan dari segi empat ke bulat. 
Adanya bentuk peralihan antara limas segitiga ke bentuk kubah, sehingga memunculkan bentuk baru merupakan sesuatu hal yang cukup menarik. Apabila dicermati hampir semua atap masjid yang bentuk kemuncaknya seperti itu memakai bahan dari kayu. Bahan tersebut berbeda dengan bahan yang dipakai untuk kubah, yaitu seng atau logam perak. Dengan demikian ada kesamaan bahan antara bentuk kemuncak segitiga dengan bentuk kemuncak segi enam ini.

Apabila dilihat pada ornamen atap maka ada dua jenis yang dapat diketahui, yaitu yang merupakan bentuk ornamen asli Kalimantan Selatan, dan yang merupakan ornamen impor. Ornamen asli terlihat pada sudut-sudut atap tumpang, berupa ukiran kayu kerawangan yang berisi ukiran tumbuh-tumbuhan. Ukiran semacam ini pada bangunan tradisional setempat dinamakan cabang atau simbar, biasanya terdapat pada ujung talang pinggiran atap. Ornamen impor terdapat pada bentuk menara-menara kecil dan hiasan di atas kubah yang berupa bulatan-bulatan kecil, lambang bulan sabit dan kadang-kadang bintang segi lima. Keduanya seringkali diidentikkan dengan lambang-lambang kebesaran Islam, dan biasanya juga terdapat pada umbul-umbul atau bendera. Secara umum sejak masa lalu di sejumlah tempat bulan dan bintang diartikan sebagai cahaya penerang pada waktu gelap (Cooper, 1993 : 107 dan 159).

Hiasan berbentuk bulatan-bulatan kecil dan bulan sabit merupakan hiasan kemuncak masjid yang populer di Afrika Utara (misalnya Mesir, Libia, dan Tunisia) dan Asia Barat (misalnya Siria, Iraq, dan Jordania). Sebagai perbandingan, di Tunis juga terdapat bangunan yang berasal dari tahun 1622 , dengan atap tumpang dua yang di atasnya terdapat hiasan berupa bilatan-bulatan kecil dan lambang bulan sabit. Di sejumlah negara Arab yang lain menara-menara kecil yang mengelilingi atap merupakan hal yang sangat populer (Michell, $1978: 221$ - 251).

Apabila dicermati terdapat perpaduan beberapa elemen arsitektur pada atap masjid di Kalimantan Selatan. Perpaduan yang sangat kelihatan adalah perpaduan antara atap yang merupakan bentuk tradisional Indonesia, yaitu atap tumpang, dan kubah yang merupakan arsitektur Timur Tengah dan India. Hal tersebut merupakan bentuk suatu kemajuan karena para pembangunnya mempergunakan beberapa elemen arsitektur yanag berbeda-beda dalam satu bangunan.

Paling tidak ada dua faktor yang mempengaruhi bentuk kemajuan tersebut, di antaranya terbukanya isolasi suatu daerah sehingga memungkinkan hubungan dengan daerah lain, serta adanya kemajuan berfikir akibat pengalaman dan tuntutan kebutuhan. Terbukanya isolasi suatu daerah menyebabkan hubungan dengan daerah lain menjadi lancar sehingga memungkinkan terjadinya kontak dalam semua segi kehidupan. Salah satu akibat adalah adanya percampuran budaya antara satu daerah dengan daerah lain sehingga memunculkan budaya yang sifatnya baru atau yang sifatnya campuran. Kemajuan berfikir akibat pengalaman dan tuntutan kebutuhan 
pada bangunan akan menampilkan berbagai corak baru. Apabila pada awalnya terdapat bangunan sederhana yang memakai bahan setempat, maka pada masa yang kemudian bangunan yang lebih megah dengan pemakaian bahan yang selektif (Abdul Rochym, 001, $1983: 35-37$ )

\section{Penutup}

Atap masjid kuna di Kalimantan berdasarkan berdasarkan bentuknya hampir semuanya mempunyai bentuk yang mirip satu sama lain. Kesamaan tersebut terutama terletak pada bentuk atap bertingkat yang dikenal dengan nama atap tumpang. Hampir semua atap atap tumpang terbuat dari sirap. Kemuncak hampir semuanya berbentuk kubah, kecuali pada beberapa masjid, misalnya Masjid Wasah Hilir yang puncaknya hanya berupa hiasan bunga-bungaan. Bentuk kubah juga bermacam-macam, yaitu bentuk kubah bawang, kubah bulat, kubah yang berbentuk seperti topi, dan kubah segi
enam. 


\section{KEPUSTAKAAN}

Atjeh, Aboebakar, 1955, Sedjarah Mesjid. Jakarta : tanpa penerbit.

Cooper, J.C., 1993, An Illustrated Encyclopaedia of Traditional Symbols. London : Thames and Hudson, reprinted.

Darwis, Raf, dan Rifai Abu (ed.), 1986, Arsitektur Tradisional Daerah Kalimantan Selatan. Jakarta : Departemen Pendidikan dan Kebudayaan.

Michell, George (ed.), 1995, Architecture of The Islamic World, Its History and Social Meaning. London : Thames and Hudson Ltd, First paperback edition.

Rochym, Abdul, (001) 1983, Mesjid Dalam Karya Arsitektur Nasional Indonesia. Bandung : Angkasa.

Wiryoprawiro, Zein M., 1986, Perkembangan Arsitektur Masjid di Jawa Timur. Surabaya : PT Bina Ilmu.

1980, Sabilal Muhtadin, Mesjid Raya Banjarmasin. Banjarmasin : Pemerintah Daerah Propinsi Kalimantan Selatan.

\begin{tabular}{|c|}
\hline PERPUSTAKAAN \\
\hline BALAI ARKEOLOGI YOGYAKARTA \\
\hline
\end{tabular}

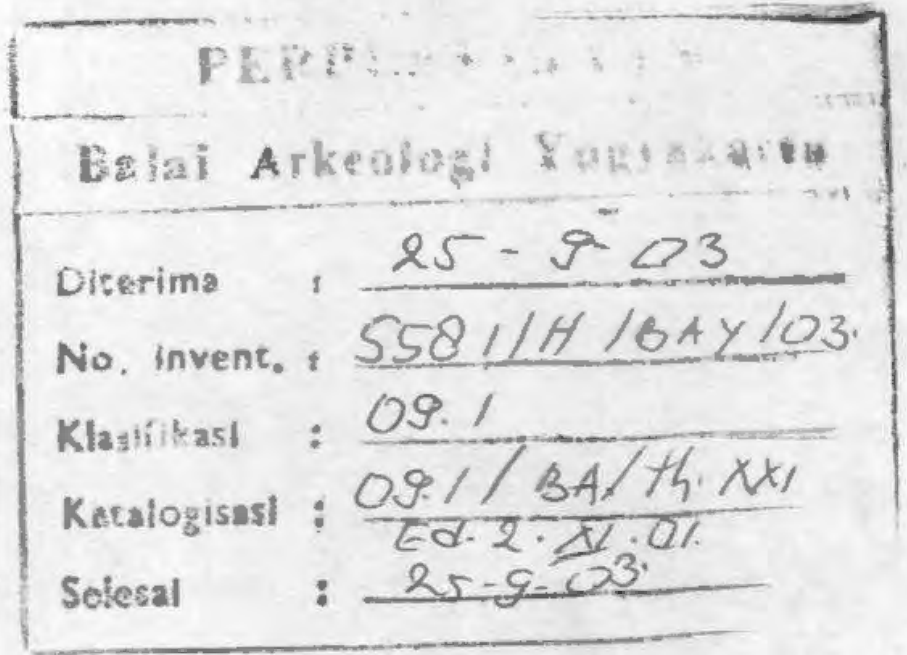

